\title{
Opinions of the Teachers Related with the Positive and Negative Aspects of the Authentic Task-Based Approach in Foreign Language Education
}

\author{
Berna KARAKOC ${ }^{1} \&$ Erdal BAY ${ }^{2}$ \\ ${ }^{1}$ School of Education, Gaziantep University, Gaziantep, Turkey \\ Correspondence: Berna KARAKOC, School of Education, Gaziantep University, Gaziantep, Turkey. E-mail: \\ bernakarakoc@gmail.com
}

Received: May 5, 2016

Accepted: May 26, 2016

Online Published: May 30, 2016

doi:10.5539/jel.v5n3p166

URL: http://dx.doi.org/10.5539/jel.v5n3p166

This study is adapted from a thesis study, PhD (2016).

\begin{abstract}
This study has been made for researching the efficacy of the authentic task-based approach in secondary school 5th grade foreign language course. Interview technique from the qualitative research method is used in the study. The data is collected through the semi-structured interviews and the opinions of the teachers. The research process is made in April-May 2015 and is carried out with 5th grade students of Kadriye Abdulmecit Özgözen Secondary School and total 52 students as to be 26 in control group and 26 in experimental group have participated to the study. The opinions of the teachers in the study related with the authentic tasks are generally considered as positive however, they mention about some negativities that may be confronted during the implementation stage.
\end{abstract}

Keywords: authentic learning, authentic task, foreign language

\section{Introduction}

As the result of the effect of the development and changes in the world on Turkish Education system, a change is applied in education programs as of the elementary school. The reasons for these changes may be factors like learn-by-rote education programs, being disconnected from daily life, being teacher-centered, inconsistence between the academic and application (Semerci \& Yelken, 2010). In addition to this, the traditional education methods where the teacher is the center, stand as obstacle in front of this change because in the classes where traditional education methods are applied, some problems occur like not determining the subjects which the students have problems, not interfering timely as the result of not expressing themselves. The countries which question their own education systems for finding efficient solutions to the problems in education fields, try different methods for solving these problems and restructuring the education system. As the result of effect of the change and developments on Turkish Education System and a change in education programs, a change is made foreign language programs which is applied in our country. Although the importance and necessity of learning foreign language is accepted by everybody, it is not possible to say that the current foreign language education achieves the desired success (Bağceci, 2004). Although knowing foreign language is very important for keeping up with the period, unfortunately the targeted success is not provided in foreign language education which starts from elementary education till the end of higher education (Çelebi, 2006). According to Özen (1978) the problems related with the foreign language education in Turkey are listed as teacher inadequacy, book inadequacy, time, environment and personal inadequacy of the students, behavior only for passing the class, crowded classrooms, modern tool and equipment inadequacy, curriculum inadequacy, inadequacies in perceiving the foreign language education and inadequacies in used methods. When the English course programs in our country are analyzed in this respect, the main purpose of the programs is to increase the interests of the students to English learning and to provide them to use this language in real life (MEB, 2013).

For finding the most efficient way in foreign language education, researches are made within the scientific frame as of the second half of 20th century and new tendencies and targets occur in foreign language education (Gömleksiz, 1997). One of these occurring approaches is the authentic learning which depends on the real life experiences for formation of a more efficient and more permanent learning. The authentic learning consists of 
the authentic tasks which are attractive and related with the real life, complicated, extraordinary, student-centered, providing the social participation of the students (Driscoll, 1994). The authentic learning depends on the solving the real problems within the life and associating this with the course subjects. It may be said that it is an approach which may help the students to find a solution by establishing a connection between their skills and knowledge from the course and the real life for overcoming the problems of daily life. We may say that it is a high level learning method in coping with the real world problems for authentic learning. The teacher is a guide and the students are the active participants in this process. Authentic activities shall provide applications of problem solving, critical thinking, knowledge synthesizing and skills in real world. An authentic learning is only provided by containing activities and tasks occurring of real world problems. Authentic learning process starts with authentic tasks and is carried out with the activities and evaluations. The authentic tasks shall be in the qualification that shall bring in knowledge and skill in situations or problems which the student may confront in today and/or in future. The authentic activities shall provide opportunity to the students in problem solving, critical thinking, synthesizing the knowledge and skills and applying in real world (Knobloch, 2003). The authentic tasks are not limited with the school and class teachers and the researches and the contemporary point of views show that the tasks which are prepared for solving the problems of real life, provide the students to learn efficiently. To prepare the authentic tasks is also very important and the points to be considered while preparing the tasks are listed as follows (Borthwick et al., 2007; Herrington, 2006);

1) to have the tasks as well-identified,

2) to have the tasks divided into sub-tasks by the students,

3) to be encouraging for the students in establishing connections with the real world and encouraging the experiences, studies of the students,

4) the supportability with the researches in many resources,

5) to be in the qualification of developing multi-perspective,

6) to have the scope that may bring high level skills related with the field,

7) to be in the qualification of establishing relation between the new information an the current information of the students,

8) to have the learnt in the qualification that is reflected as individually and cooperative,

9) to be in the qualification that may form interdisciplinary learning,

10) the applicability of the information and skills in different subjects and providing the integrity,

11) providing an assessment which is integrated with the main task and reflecting the assessment of real world,

12) providing opportunity for producing new information,

13) to be in the qualification of being completed in a long period.

There are some points to be considered by the teachers while preparing the authentic tasks. The teacher shall consider the specifications of the class environment while preparing an effective authentic task. Besides, by guiding the students in how the authentic tasks shall be fulfilled and how their learning shall be actualized, more efficient results can be obtained (Newmann \& Wehlage, 1993). The guidance of the teacher to the students plays an important role in this kind of tasks. If there is no tasks which is well-structured or with any support given by a teacher, the students may not develop their knowledge and skills while coping for fulfilling the authentic tasks successfully. The teachers shall encourage the studies of the students and shall prepare real life environment that shall encourage them and shall provide them for taking risks for fulfilling the tasks.

Consequently, if it is considered that the main purpose of English course program is to increase the interest of the students in learning English and to provide the usage of this language in real life; the opportunity of establishing communication with outer world may be provided with the authentic tasks in authentic learning approach by bringing the real life problems into classroom. When the current problems in foreign language education are considered, the necessity of actualizing the foreign language education not within a lamp glass but within a society confronts us as one of the most important factors. Thus, environments must be created for having the education more significant and permanent for the students in language education process with the authentic activities where the students may apply their information in their own lives (Çakır, 2014). Therefore, authentic learning and authentic tasks have an important place in education process. In this research, the opinions of the teachers related with the usage of the authentic tasks in secondary school foreign language education. 


\section{Method}

In this study, qualitative research method is used. The qualitative research techniques have important specifications like the participant role of the researcher, providing sensitiveness to the natural environment, having a totalitarian approach, providing the presentation of perceptions, having an integrated approach, the flexibility of the research pattern, and having a reasoning analysis (Yıldırım \& Şimşek, 2011). Interview technique from the techniques used in the qualitative research approach, is used in this study.

\subsection{Participants}

The study is made with 4 teachers in Gaziantep province secondary school 5, 6, 7 and 8th grade English classes for determining their opinions related with the authentic tasks. The specifications of the teachers are shown in below table.

Table 1. The specifications of the participants

\begin{tabular}{lcc}
\hline & AGE & SENIORITY(year) \\
\hline 1. Teacher (gül) & 32 & 9 \\
2. Teacher (fulya) & 30 & 4 \\
3. Teacher (aycan) & 27 & 5 \\
4. Teacher (deniz) & 33 & 12 \\
\hline
\end{tabular}

\subsection{Data Collection Tool}

The interviews made with the teachers form the data collection tool of the research. The interviews are made by using a semi-structured interview form with each teacher in 2015, May. The teachers participated to the interviews voluntarily and mentioned that they shall reply the questions honestly. The interviews were recorded with the recorder. The records were written. The recorded data were evaluated with the content analysis method and the coding was made. The codes were controlled by 2 researchers and the convergent validity was determined as approximately $92 \%$. The different codes were reviewed by converting into the common opinion.

The questions in interview form are developed by the researcher for making a detailed examination on the opinions of the teachers who help in actualizing the authentic tasks process. The literature scanning is made, interviews are made with the teachers and the items are written as draft for determining the questions in interview. Some items are eliminated and issued by taking the opinions of 3 experts. The final state is viewed by the linguists and the skeleton form of the interview questions is prepared and same questions are asked to all participants during the interview. The questions asked to the questions are mainly as follows:

1) What are the positive aspects of the practice of this study?

2) What are the negative aspects of the practice of this study?

\subsection{Analysis of the Data}

In the analysis of the data, content analysis method is used. The content analysis can be expressed as commenting and regulating the similar data in the form that the reader can understand by gathering the data within frame of specific concepts and themes (Yıldırım \& Şimşek, 2011). The coding is formed according to the concepts which are obtained from qualitative data.

In this section of the study, for determining how the authentic task usage in foreign language education is evaluated by the teachers, 2 different themes are determined under the title of pros and cons of the implementation. The pros of the implementation express the positive aspect of the implementation and the cons of the implementation express the negative aspects of the implementation. The themes are determined according to the interview questions. 19 codes are determined at the end of the analysis which is made according to the 2 themes. In the analysis of the data obtained from the interviews, direct opinions of the participants sampling the codes, are used. The direct transfers are given together with the numbers given to the participants (T1, T2, T3 and T4). 


\section{Findings}

While forming the themes, coding is related with the opinions of each teacher and his/her replies in accordance with the asked questions.

\subsection{Findings Related with the Opinions of the Teachers about What the Positive Aspects of the Practice of This Study Are}

In this section, the opinions of the teacher related with the question "What are the positive aspects of the practice of this study?" are turned into tables by forming themes and codes.

Table 2. Thematic and conceptual coding related with the opinions of the teachers about the positive aspects of the practice of this study

\begin{tabular}{lll}
\hline \multicolumn{1}{c}{ Themes } & & \multicolumn{1}{c}{ Coding } \\
\hline \multirow{2}{*}{ Positive Aspects } & $\checkmark$ & to form an appropriate environment for each subject and to \\
& $\checkmark$ & To be in natural environment (T3, T4), \\
& $\checkmark$ & To be entertaining (T1), \\
& $\checkmark$ & An efficient method (T4), \\
& $\checkmark$ & Provides motivation (T3), \\
& $\checkmark$ & Provides permanent learning (T1, T4), \\
& $\checkmark$ & They use the language by using in the daily life (T4), \\
$\checkmark$ & Provides them to make practice (T2), \\
$\checkmark$ & It develops the pronunciation (T2), \\
$\checkmark$ & They improve positive attitude for the course (T4). \\
\end{tabular}

All of the teachers who participate to the research in the concepts formed according to the opinions related with the positive aspects of the practice of this study, have expressed the positive aspects in the practice of this study as follows; to form an appropriate environment for each subject and to make implementation, to be in natural environment, being an efficient method, providing motivation, providing permanent learning, using the language in daily life, providing them to make practices, to develop the to pronunciation, to improve positive attitude for the course.

All teachers in the research express the positive aspects in the practice of this study in various form. The teacher $\mathrm{T} 1$ who expresses that forming an appropriate environment for the subject and the implementation in this environment, is the most positive aspect and expresses that "To form an appropriate environment for each subject and to make implementation in this environment is the most positive aspect. To teach the subject by applying in its own environment, shall be more entertaining and permanent". Besides related with the persistency of the courses which is designed with the authentic tasks in foreign language teaching, the teacher T4 expresses that "I think that using English in daily life provides more permanent learning". The teacher T2 who expresses that there are many positive aspects for the positive aspects of the implementation and adds "There are many positive aspects which I consider as positive in the implementation. I think that the students develop their practicing talents with the exercises. I think that they develop their pronunciation by using English". With this expression, it may be commented that forming environments which the students shall use English, gives positive results in terms of language development of the student.

The teacher T3 who expresses that being in natural environment while learning language, is a positive aspect for the motivation of the students, adds "Providing the students to be in the natural environment related with the subject while learning foreign language, makes contribution to them in understanding the subject by hearing and talking, seeing within the environment and in better motivating in the subject". Like T3, the teacher T4 who mentions about the positive aspects of the course in natural environment, adds "The student learns to use the language by applying and living in the actual environment instead of learning language in virtual environment in classes of the school". T4 thinks that developing positive attitude against the course, is an efficient method for the positive aspects of the implementation and adds "I think that more permanent learning actualizes by using 
English in daily life. It is a very sufficient method in developing a positive attitude towards the course. The students learn to use the language by living in actual life instead of teaching language in virtual environment in classes of the school'".

\subsection{Findings Related with the Opinions of the Teachers about What the Negative Aspects of the Practice of This Study Are}

In this section, the opinions of the teacher related with the question "What are the negative aspects in the practice of this study?" are turned into tables by forming themes and codes.

Table 3. Thematic and conceptual coding is related with the opinions of the teachers about the negative aspects of the practice of this study

\begin{tabular}{lll}
\hline Theme & Conceptual coding/ Concepts and sub-concepts \\
& $>$ & None (negative aspect) (T2), \\
& $>$ & Available (negative aspect), \\
Negative Aspects & $\checkmark$ & Transportation (T3), \\
& $\checkmark$ & Permit (T1), \\
& $\checkmark$ & Procedure (T1), \\
& $\checkmark$ & Individual communication is hard due to being crowded (T3, T4), \\
& $\checkmark$ & Deficiencies in manuals(T4), \\
& & Time problem (T3), \\
& & Its preparation is hard for the teacher (T4). \\
\hline
\end{tabular}

The concept which is formed for the negative aspects of the practice of this study, is in the form of none (negative aspect) and available (negative aspect). The teachers who express opinions as available, have expresses the negative aspects like; transportation problem, problems in obtaining permit, procedures to be applied, individual communication problems occurring from the crowded classes, deficiencies in manuals, time problem and hard preparation for the teacher.

Only one teacher T2 who mentions that she has not seen any negative aspects related with the negative aspects of the practice of this study and adds "I have seen no negative aspects in the practice of this study". 3 of the teachers in the research express the negative aspects in various forms. The teacher T1 who thinks that there are some problems in preparing the environment for the course, adds "Problems in preparing appropriate environment for the subject (for depending on the conditions like various permits, procedures." With this expression, it is understood that the teacher thinks that to take the essential permits in the implementation stage beclouds the implementation while preparing the appropriate environment for the subject. T3 who mentions that there are some transportation problems in providing the implementation out of the school and adds "In providing the natural environment out of school in some implementation, some problems occur in terms of transportation and time. The high number of the students makes the individual communication with the students harder." Besides, T4 who mentions about the problem of peer-to-peer communication with the students in crowded classes as a negative aspect, expresses "It is hard for the teacher to take care of the students due to the crowded classes..." With this expression, it is understood that it is hard to perform peer-to-peer communication in the crowded classes.

T4 who mentions that the designing courses is a troublesome work for the students and adds "...To design courses is troublesome for each course because in the guide books of MEB, there is no guidance activity for this. The teacher needs to plan courses separately for each course and class". With this expression, it is understood that the designing separate courses for each subject and the implementation is hard and the essential information is not sufficient in the guide books for the teachers. 


\section{Discussion}

As the result of the analysis of semi-structured interviews with English teachers helping in actualizing the activities during research process related with the authentic tasks process, it is concluded that the teachers have many different opinions related with the authentic tasks in foreign language education. They have expressed some various opinions like teaching a lesson by preparing authentic tasks in foreign language education is effective on the motivation of the students, to prepare actual environment provides the students to make practices in terms of development of the language, the authentic activities make the courses more fun for the students and permanent learning occurs and the students develop a positive attitude against the course. To the question "what are the positive aspects in the practice of this study?" and to the question which is qualified as the "positive aspects" themes, all of the teachers in the research express the positive aspects as; to prepare an appropriate environment for each subject and to make implementation, to be in natural environment, to be an efficient method, to provide motivation, to provide permanent learning, to use the language by using in daily life, to provide the students to make practice, to develop the pronunciation, to develop positive attitude against the course.

As the result of the analysis of the interviews made with the students of high schools where English is taught as the foreign language, Güçlü Kale (2010) expresses that the students present positive attitude against the word learning by using authentic video and the word teaching becomes easier and amusing. In similar study, Bay and Karakaya (2008) try to determine the opinions of the teacher candidates related with the authentic tasks in learning environment based on the constructivist approach and conclude that the opinions of the teacher candidates related with the authentic tasks as encouraging, beneficial, positive, amusing, creative, and satisfactory.

To the question "What are the negative aspects in the practice of this study?" and to the question which is qualified as the "negative aspects" themes, the coding which is formed related with the opinions of the teachers in the research for the negative aspects of the practice of this study, is mentioned as none (negative aspect) and available (negative aspect). The teachers who express opinions as available, express the negative aspects of the implementation as; problems in transportation, problems in obtaining permit, procedures that are required to be applied, individual communication problems arising from the crowded classes, deficiencies in guide books, time problem and hard preparation for the teacher. Besides the positive aspects of the implementation of the authentic tasks on the students, there are some negative and hard aspects which are mentioned by the teacher. Some of them are, inadequate time of the courses, hardness in preparation, insufficiency of the school environment in terms of physical aspects. As another result of the study of Bay and Karakaya (2008), they express the factors which negatively affect the opinions of the preservice teachers related with the authentic tasks as technical problems, timing and planning, failure in organizing the individuals, failure in camera and computers during the presentation of these tasks and actualizing these tasks. In the study made by Akar (2003), the teacher candidates express that the authentic activities are not easy and comfortable. Besides, in the study made by Reeves et al. (2002), the authentic tasks are formed of the complex targets which are needed to be solved by the students in a specific period of time and the tasks must be actualized in a long period of time and therefore the short period of time given to the students may affect the opinions of the students negatively. The thought which is similar to the opinion of the teacher expressing opinion related with the deficiencies in the guide books, occurs in the study made by Gilmore (2007). He has made a wide research related with the problems about the authentic materials and authenticity in foreign language education and he has presented suggestions for four problems related with the effects and design of the tasks in language acquisition and hardness in the texts, authenticity and motivation and discussing English as a world language and the difference between the authenticity and the course books.

\section{References}

Akar, H. (2003). Impact of constructivist leraning process on preservice teacher education students' performance, retention and attitudes. Yayımlanmamıs Doktora Tezi, Ankara: Ortadoğu Teknik Üniversitesi Sosyal Bilimler Enstitüsü.

Bağceci, B. (2004). Ortä̈ğretim kurumlarında İngilizce öğretimine ilişsin öğrenci tutumları (Gaziantep ili örneği). Ulusal Eğitim Bilimleri Kurultayı, Malatya: İnönü Üniversitesi, Eğitim Fakültesi.

Bay, E. (2008). Öğretmen eğitiminde yapılandırmacı program uygulamalarının etkililiğinin değerlendirilmesi (Unpublished Doctoral Dissertation). Atatürk Üniversitesi, Erzurum.

Borthwick, F., Bennett, S., Lefoe, G. E., \& ve Huber, E. (2007). Applying authentic learning to social science: A learning design for an inter-disciplinary sociology subject. Journal of Learning Design, Designing For Effective Learning, 2(1), 14-24. 
Çakır, G. (2014). Yabancı Dil Olarak Almanca Öğretiminde Özgünlük ve Kurgu'nun Yeri ve Önemi. Route Educational \& Social Science Journal, 1(1).

Çepni, S. (2005). Araştırma ve proje çalı̧̧malarına giriş. Ankara: PegemA yayıncılık.

Driscoll, M. P. (1994). Psychology of learning for instruction. Boston: Allyn and Bacon.

Gilmore, A. (2007). Authentic materials and authenticity in foreign language learning. Language teaching, 40(2), 97-118. http://dx.doi.org/10.1017/S0261444807004144

Gömleksiz, N. (1997). Yüksekögretimde Yabanci Dil Ögretimi ve Sorunlari. Türkiye, Türk Cumhuriyetleri ve Asya Pasifik Ülkeleri Uluslar arasi Egitim Sempozyumu.

Güçlü Kale, N. (2010). Using Authentıc Video In Teaching Vocabulary in Turkish Secondary Level Efl Classrooms (Unpublished master's thesis). Muğla Üniversitesi, Muğla.

Herrington, J. (2006). Authentic e-learning in higher education: Design principles for authentic learning environments and tasks.

Knobloch, N. A. (2003). Is experiential learning authentic? Journal of Agricultural Education, 44(4), 22-34. http://dx.doi.org/10.5032/jae.2003.04022

MEB. (2005). İlköğretim Sosyal Bilgiler Dersi Öğretim Programı Ve Kılavuzu. Ankara, MEB Yayınevi.

Newmann, F. M., \& Wehlage, G. G. (1993). Five standards of authentic instruction. Educational Leadership, 50, $8-12$.

Reeves, T. C., Herrington, J., \& Oliver, R. (2002). Authentic activities and online learning.

Semerci, N., Yelken, T. Y., \& Fırat, Ü. (2010). İlköğretim Programlarındaki Ortak Temel Becerilere İlişkin Öğretmen Görüşleri (Elazı̆̆ İli Örneği).

Yıldırım, A., \& Şimşek, H. (2011). Sosyal bilimlerde nitel araştırma yöntemleri. Ankara: Seçkin yayınevi.

\section{Copyrights}

Copyright for this article is retained by the author(s), with first publication rights granted to the journal.

This is an open-access article distributed under the terms and conditions of the Creative Commons Attribution license (http://creativecommons.org/licenses/by/3.0/). 